\title{
Naloxone as an antidote for angiotensin converting enzyme inhibitor poisoning: a case report
}

\author{
Vatsal Trivedi, MD, FRCPC (1) Bryan A. Glezerson, MD, FRCPC - Dipayan Chaudhuri, MD, FRCPC • \\ Morgan Davidson, MSc, RN • Ghislaine Douflé, MD
}

Received: 4 March 2020/Revised: 18 April 2020/Accepted: 19 April 2020/Published online: 27 April 2020

(c) Canadian Anesthesiologists' Society 2020

\section{To the Editor,}

A 48-yr-old female $(102 \mathrm{~kg})$ with hypertension presented to a community hospital with intentional ingestion of amlodipine $(252 \mathrm{mg})$ and perindopril (180 $\mathrm{mg})$. She received $4 \mathrm{~L}$ intravenous crystalloid and

\author{
V. Trivedi, MD, FRCPC ( $\square)$ \\ Interdepartment Division of Critical Care Medicine, Toronto \\ General Hospital, University of Toronto, Toronto, ON, Canada \\ e-mail: vatsal.trivedi@uottawa.ca
}

\section{B. A. Glezerson, MD, FRCPC}

Department of Anesthesiology and Pain Medicine, Brigham and Women's Hospital, Harvard Medical School, Boston, MA, USA

Department of Anesthesia, Critical Care, and Pain Medicine, Massachusetts General Hospital, Harvard Medical School, Boston, MA, USA

D. Chaudhuri, MD, FRCPC

Department of Medicine, McMaster University, Hamilton, ON, Canada

M. Davidson, MSc, RN

Medical-Surgical Intensive Care, University Health Network, Toronto, ON, Canada

Institute of Health Policy, Management and Evaluation, University of Toronto, Toronto, ON, Canada

\section{G. Douflé, MD}

Interdepartment Division of Critical Care Medicine, Toronto General Hospital, University of Toronto, Toronto, ON, Canada

Medical-Surgical Intensive Care, University Health Network, Toronto, ON, Canada

Department of Anesthesia and Pain Management, Toronto, General Hospital, University Health Network, Toronto, ON, Canada norepinephrine to maintain a mean arterial pressure $>65$ $\mathrm{mmHg}$. She received activated charcoal with subsequent aspiration. Her evolving vasoplegia required norepinephrine $1 \mu \mathrm{g} \cdot \mathrm{kg}^{-1} \cdot \mathrm{min}^{-1}$, vasopressin $8 \mathrm{U} \cdot \mathrm{hr}^{-1}$, epinephrine $0.55 \mu \mathrm{g} \cdot \mathrm{kg}^{-1} \cdot \mathrm{min}^{-1}$, and high-dose insulin euglycemia therapy (HIET) with $10 \quad \mathrm{U} \cdot \mathrm{kg}^{-1} \cdot \mathrm{hr}^{-1}$ Humulin ${ }^{\circledR}$ (Eli Lilly \& Company, Indianapolis, IN, USA). A transthoracic echocardiogram revealed normal biventricular function. Her hypoxemia necessitated transfer to a quaternary care centre, where she received lung protective ventilation, deep sedation (midazolam and fentanyl), paralysis (cisatracurium), prone positioning, and inhaled nitric oxide. This management was continued for the first $72 \mathrm{hr}$ of admission, following which her hypoxemia improved. Her sedation was de-escalated to propofol only. Over the subsequent $24 \mathrm{hr}$ (four days postadmission), the HIET was weaned rapidly as insulin sensitivity improved, a marker of recovery from calcium channel blocker poisoning.

At this point, based on toxicologic pharmacokinetics and discussion with the Regional Poison Centre, there was concern for ongoing perindopril overdose causing vasoplegia. Given this, the patient was treated with intravenous naloxone in attempt to treat vasoplegia secondary to angiotensin converting enzyme (ACE) inhibitor. She received $200 \mu \mathrm{g}$ aliquots of intravenous naloxone every three to five minutes to a total dose of 1.6 mg. Over the subsequent hour, her vasopressor requirements decreased. Rebound hypotension was noted four hours after administration of naloxone. An infusion was initiated and continued for a total of $48 \mathrm{hr}$, over which her vasopressors were weaned completely (Figure). The total dose of naloxone received was approximately 10.6 $\mathrm{mg}$. She showed no subjective or objective signs of pain or discomfort (reported pain, tachycardia, ventilator 


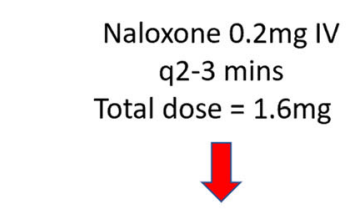

$\underline{0 \text { hour }}$

NOREPI $90 \mathrm{mcg} / \mathrm{min}$

VASO $6 \mathrm{U} / \mathrm{hr}$

$\mathrm{EPI} 45 \mathrm{mcg} / \mathrm{min}$

Figure Vasopressor requirements during administration of naloxone started $96 \mathrm{hr}$ after admission. The infusion was carried out for a total of $48 \mathrm{hr}$ with a total administered dose of $10.6 \mathrm{mg}$. Vasopressors were

asynchrony). She was uneventfully extubated on postadmission day 7 and discharged from the intensive care unit for ongoing medical and psychiatric care.

Toxicity from ACE inhibitors manifests with multisystem derangements, with severe toxicity producing profound hypotension, acute renal failure, respiratory distress, and altered mentation secondary to central hypoperfusion. ${ }^{1}$ Management is generally supportive with maintenance of normal blood pressure and perfusion. ${ }^{1}$ Naloxone is a competitive opiate receptor antagonist used traditionally for opioid overdose. Previous reports suggest the use of naloxone to reverse captopril overdose $^{2,3}$ but no recommendation exists for this indication.

The challenge our case presented was a mixed overdose of amlodipine and perindopril. Toxic pharmacokinetics suggested that toxicity from amlodipine would be approximately four to five days, with a more prolonged duration of perindopril toxicity (approximately seven days) because of the active metabolite perindoprilat. Our case showed improvement in hemodynamics temporally associated with naloxone administration during perindopril overdose. The mechanism for this finding appears to depend on the effect of ACE inhibitors on the endogenous opioid system, particularly on the antagonism of enkephalinase. This leads to accumulation of enkephalins, which increase vasodepressor activity and inhibit central angiotensin II activity. ${ }^{3,4}$ One may postulate that the effect on hemodynamics was secondary to sympathetic activity and/or pain from naloxone administration. Previous literature shows that administration of naloxone to opioid-naive humans has no noticeable effects. ${ }^{5}$ Our patient mounted no objective or subjective features of pain/discomfort, and notably did not
Naloxone $0.4 \mathrm{mg}$

then

$200 \mathrm{mcg} / \mathrm{hr}$

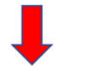

$\underline{5 \text { hour }}$

8 hour

NOREPI $55 \mathrm{mcg} / \mathrm{min}$

NOREPI $30 \mathrm{mcg} / \mathrm{min}$

VASO $4 \mathrm{U} / \mathrm{hr}$

VASO off

EPI off

EPI off

weaned as tolerated to maintain mean arterial pressure $>65 \mathrm{mmHg}$. $\mathrm{EPI}=$ epinephrine; NOREPI $=$ norepinephrine $; \mathrm{VASO}=$ vasopressin

endorse any recollection of pain when extubated and interviewed. No complications of this therapy, or usual side effects such as vomiting, were identified.

Angiotensin converting enzyme inhibitor poisoning leads to multisystem failure secondary to systemic hypoperfusion. In the presence of profound vasoplegic shock secondary to ACE inhibitor poisoning, naloxone may be used to overcome the excess vasodepressor activity of endogenous opioids.

Disclosures None.

Funding statement None.

Editorial responsibility This submission was handled by Dr. Hilary P. Grocott, Editor-in-Chief, Canadian Journal of Anesthesia.

\section{References}

1. Lucas C, Christie GA, Waring WS. Rapid onset of haemodynamic effects after angiotensin converting enzyme-inhibitor overdose: implications for initial patient triage. Emerg Med J 2006; 23: 8547.

2. Varon J, Duncan SR. Naloxone reversal of hypotension due to captopril overdose. Ann Emerg Med 1991; 20: 1125-7.

3. Ajayi AA, Campbell BC, Rubin PC, Reid JL. Effect of naloxone on the actions of captopril. Clin Pharmacol Ther 1985; 38: 560-5.

4. Di Nicolantonio R, Hutchinson JS, Takata Y, Veroni M. Captopril potentiates the vasodepressor action of Met-enkephalin in the anaesthetized rat. Br J Pharmacol 1983; 80: 405-8.

5. El-Sobky A, Dostrovsky JO, Wall PD. Lack of effect of naloxone on pain perception in humans. Nature 1976; 263: 783-4.

Publisher's Note Springer Nature remains neutral with regard to jurisdictional claims in published maps and institutional affiliations. 